It would, unfortunately, be extremely difficult to trace all the medical men to whom a copy of the brochure in question has been sent already, but we can certainly assure you that no other copies will be issued containing the quotation to which you refer.

If we have your permission we should be glad of the opportunity of reprinting the whole of your article and issuing it with the brochure, calling attention to the discrepancies so that those interested may ascertain for themselves your exact statement.

We have been the more sorry for this occurrence as in the past your article has been of much value in securing the extended use of collosol argentum, which is now almost universally employed by ophthalmic surgeons. You will doubtless remember that you were practically the pioneer in utilising and publishing the results of your investigations, and we should, indeed, hold ourselves in contempt if any intentional action on our part was likely to cause inconvenience or trouble to a member of the medical profession to whose kindly interest we owe much.

$$
\begin{aligned}
& \text { Yours faithfully, } \\
& \text { For BRITISH Colloids, Limited, } \\
& \text { (Signed) E. H. Buckman, General Manager. }
\end{aligned}
$$

I am, Sir, Yours truly,

A. LegGe Roe.

HuLL, March 15, 1922.

\title{
SCLERO-CORNEAL TREPHINING AND HOLTH'S EXTRALIMBAL TANGENTIAL SCLERECTOMY
}

To the Editor of ThE British Journal of Ophthalmology SIR,-Will you allow me some words in reply to Lieut.-Colonel R. H. Elliot's letter in your March issue (p. 141). He qualifies as a " serious error" my quotation of Duane's additional note in Fuchs's Text-book of Ophthalmology, 6th American edition, 1919, p. 512. I admit that I ought to have quoted literally. " according to some " instead of " according to American operators," though Duane's additional notes generally concern experiences in America. I don't know if some of European statistics have " about 7 per cent" of late infections after sclerectomies, though Professor J. Meller, in his "Manual of Ophthalmic Operations," 1921 , p. 333 , speaks of the "terrific frequency" of this calamity after sclero-corneal trephining.

When Mr. Elliot writes: "Duane makes it absolutely clear that he is speaking of sclerectomy as a whole, and not of any single 
operation, . . . I must be permitted to present in italics Duane's first line in his note, quoted by Mr. Elliot himself in his letter: " (Sclerectomy, more particularly in the form of the Elliot trephining operation, . . .").

The fact that far more cases of late infection have been seen after sclero-corneal trephining than after any other form of sclerectomy is due not only to Elliot's operation having had the overwhelming majority of adherents but also to the fact that this operation-in spite of splitting of the cornea-gives a thinner conjunctival covering than the other sclerectomies. I saw myself not a single case of the late infection after my punch forceps sclerectomies from the anterior wound lip executed 1908 to 1913 , but I have seen two cases later after the publication of Harrison Butler's " tragedy"; in these sclerectomies the scleral defect was very near the limbus.

I know no safer method of placing the anterior border of an effective scleral excision a good millimeter away from the limbus and by this means obtaining a thicker and better vascularized conjunctival covering than my tangential extra-limbal sclerectomy with the new $1 \mathrm{~mm}$. punch forceps described in the December issue of this journal 1921, pp. 547-551. In Christiania since April, 1920 , this operation is in constant use besides by myself by Professor Hj. Schiötz and Professor Sigurd Hagen in all the cases of primary chronic glaucoma which need operation. Till now no case has been followed by late infection; this may come later but I have very good reasons to believe much more rarely than after previous sclerectomies opening the anterior chamber.

Christiania, Norway. Yours truly,

March 10, 1922.

S. Holth.

\section{NOTES}

As recorded in our last number $\mathrm{Mr}$. Charles

\section{Deaths}

Wray has died in a London nursing home. We now give some details of his life and career.

He was born in 1858 at Long Marston, Yorks, and was the only son of William Wray. He lost his mother when he was a few months old. In 1887 he married Henrietta Elizabeth, the second daughter of Henry Walmesley Welch, of Quebec. There were no children. He received his general education in Yorkshire and his medical education at the London Hospital. His expert knowledge of shorthand and drawing was of great assistance to him in his work. He was appointed ophthalmic surgeon to the Croydon General Hospital in 1887, and held the post until almost the last, 